
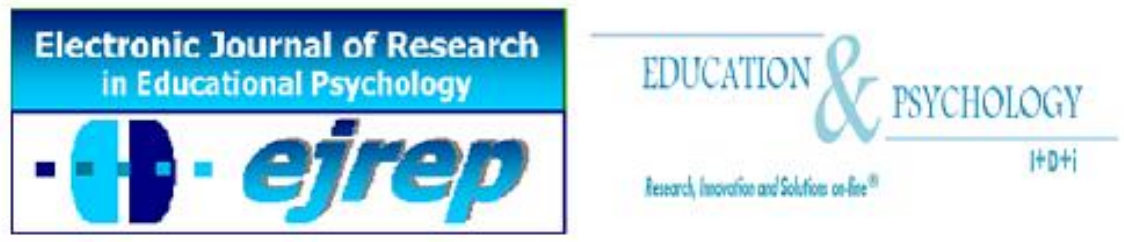

Ilustre Colegio Oficial

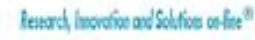

\title{
Spanish Zimbardo Time Perspective Inventory Construction and Validity among Higher Education Students
}

\author{
Mireia Usart ${ }^{1}$, Margarida Romero ${ }^{1,2}$ \\ ${ }^{1}$ ESADE Law and Business School, Universitat Ramón Llull, Barcelona \\ ${ }^{2}$ Department of Teaching and Learning Studies, Université Laval, Québec
}

\section{Spain/ Canada}

Correspondence: Mireia Usart. ESADE Law and Business School, 60-62 Avenue Pedralbes, 08034 Barcelona, Spain. E-mail: mireia.usart@esade.edu

(C) Education \& Psychology I+D+i and Ilustre Colegio Oficial de Psicología de Andalucía Oriental (Spain) 


\begin{abstract}
Introduction. The study of Time Orientation (TO) has been focused on how to measure this construct and its effects on human behavior. Defined as a fundamental psychological variable, TO is multidimensional, sensible to cultural differences and age. Although its relation to learning, it deserves further study in the different Higher Education (HE) modalities (onsite, blended and online).
\end{abstract}

Method. Exploratory factor analysis (EFA) is used in a sample of $250 \mathrm{HE}$ learners enrolled in online, blended and onsite institutions, to compare the results of the ZTPI in the particular population of HE students in relation with the previous studies in English and those using the ZTPI Spanish release among a general population sample. Also, Confirmatory Factorial Analysis (CFA) is conducted among a different sample $(n=316)$ in order to discuss the external validity of the instrument.

Results. The factorial structure study of the ZTPI in Spanish among HE students revealed 5 factors, with a similar item classification of the previous study of the Spanish release and an acceptable internal reliability for each factor. Furthermore, the study of TO in relation to age for students in three different university modalities showed significant differences for past and future orientations and present hedonism when compared with previous research, culturan aspects are discussed. In general, the ZTPI in Spanish is a reliable instrument for measuring the students' TO, and this psychological trait is significantly related to age and university modality.

Discussion. Our results could give a first, indicative direction for helping institutions adapting their offer of online, onsite and blended courses to the different students' profiles, based on their TO. Moreover, differences shown among contexts could also guide prospective HE students to choose the best fitted HE modality according to their TO.

Keywords: Time Perspective, Temporal Orientation, Higher Education, Age, ZTPI. 


\section{Construcción y validez de una versión española del Zimbardo Time Perspective Inventory en estudiantes de enseñanza superior}

\section{Resumen}

Introducción. El estudio de la orientación temporal (TO) se ha centrado en cómo medir este constructo y en sus efectos sobre el comportamiento humano. Este constructo se define como una variable psicológica fundamental, de carácter multidimensional, y sensible a las diferencias culturales y de edad. Aunque se ha relacionado con el aprendizaje, merece un estudio detallado en las diferentes modalidades actuales de Educación Superior (presencial, mixta y en línea).

Método. El análisis factorial exploratorio (EFA) es utilizado para estudiar los factores del Zimbardo Time Perspective Inventory (ZTPI) en la población correspondiente a alumnos universitarios. Una muestra de 250 estudiantes matriculados en tres instituciones de educación superior, una universidad en línea, una con metodología mixta y una universidad presencial respondieron al test. Se comparan los resultados con los estudios previos en inglés y español, para medir tanto las diferencias culturales como aquellas debidas al perfil concreto de participante. Finalmente, se realiza un análisis factorial confirmatorio (CFA) para estudiar la validez externa del instrumento en una muestra diferente de 316 estudiantes.

Resultados. El estudio de la estructura factorial del ZTPI en español entre los estudiantes universitarios reveló 5 factores, con una clasificación de los items similar al estudio previo de la versión española del ZTPI y una validez interna aceptable para cada factor. Por otra parte, el análisis de la TO en relación con la edad de los estudiantes en tres modalidades universitarias distintas muestra diferencias significativas en las orientaciones futura, pasada y presente hedonista que se discuten respecto a estudios anteriores en función de diferencias culturales. En general, el ZTPI en español es un instrumento fiable para medir la TO de los estudiantes. Este constructo se relaciona significativamente con la edad y la modalidad universitaria en la muestra estudiada.

Discusión. Los resultados pueden ayudar a las instituciones para adaptar su oferta a los diferentes perfiles de los estudiantes, en función de su TO. Por otra parte, las diferencias mostradas entre contextos también pueden guiar a futuros estudiantes en la elección de la modalidad que mejor se ajuste, en función de su TO.

Palabras Clave: Perspectiva Temporal, Orientación Temporal, Educación Superior, Edad, ZTPI 


\section{Introduction}

Humans have a subjective perception of time (Lewin, 1942). Due to this capacity, individuals and cultures can experience time in different manners. This psychological concept is named psychological time, and following Nuttin (1964), it can be approached from the study of individual differences, and how influence the human perception of time. Three individual constructs can be the generators of the so-called psychological time: time attitude (TA), time orientation (TO), and time perspective (TP). The intrapsychological factors of time perception and perspectives have been analyzed by psychologists and sociologists in recent decades primarily in North America (Block, 1974; Zakai, 1989; Zimbardo \& Boyd, 1999). Researchers have historically attempted to measure and define these concepts with unequal results. Nevetheless, TO has succeed to be one of the intrapsychological factors of time with a wide corpus of research, in particular, regarding educational variables, since 1942, with a first definition of TO by Lewin. TO is a multidimensional construct to measure individuals' temporal orientation, related to different behaviors. In particular, educational psychologists have studied TO as a predictor variable for different learning outcomes and processes (Malka \& Covington, 2005; Van der Veen \& Peetsma, 2011). This construct is defined by Zimbardo, Keough and Boyd (1997, p. 1008) as the manner in which individuals, and cultures, partition the flow of human experience into distinct temporal categories of past, present and future. These authors also defined and validated a measuring instrument, the Zimbardo Time Perspective Inventory (ZTPI) in order to reliably measure TO. However, as this construct is, by definition, related to cultural differences, the ZTPI deserves further study when implementing it in cultures different than North-American original study sample, such the Brazilian (Milfont, Andrade, Belo, \& Pessoa, 2008), the Swedish (Carelli, Wiberg \& Wiberg, 2011) or the Spanish contexts (Díaz-Morales, 2006).

The research in the field of TO in Spain has been very limited. In 2006, Díaz-Morales translated and studied the factorial structure and reliability of the ZTPI among a sample of 756 Spanish adults, taking into account their level of studies, and relating TO to age and gender differences. Our study aims to continue with the work on the ZTPI factor analysis and its reliability done by Díaz-Morales among a sample of Spanish adults, but focusing on Spanish academic context, in particular, we focus on Higher Education (HE) students' TO. 
Previous research has highlighted the differences between the adult population in general and the particular HE students population (Rodríguez \& Agulló, 1999). However, these differences have not been studied in the Spanish context in terms of their TO. In order to characterize HE students' TO, the first objective of this study is to test the validity of the Spanish version of the ZTPI among a sample of HE learners, and studying, first, the possible relation between the students' TO and their age, and second, students' TO and the three main HE modalities existing in Spain: onsite learning, blended or hybrid learning and online learning.

The paper starts by presenting the ZTPI as an instrument to measure the individuals' TO, and then introduces the current modalities of Higher Education (HE) in Spain and the specificities of the HE students' profiles. Next, the study analyses the validity of the Spanish version of the ZTPI among a sample of 250 Spanish students from three different HE modalities, in order to investigate the relation between TO and students' age, and the relation between TO and the three different HE learning modalities (onsite, blended, online). We further discuss the consequences of these relations, both for HE learning institutions and for students when choosing to enroll in a certain HE modality.

TO has been defined from different perspectives since Lewin's (1942) study. This is a not situation specific construct (Nurmi, 1991), and has been compared and sometimes measured as Time Perspective; a multidimensional trait with extension and valence that is different for each life domain (Gjesme, 1983). Different authors claimed for a clear definition of this psychological concept and highlighted that TO have historically been defined and therefore measured using different questionnaires to measure this construct (Díaz-Morales, 2006; Fourez, 2009). Nevertheless, since the Zimbardo, Keough and Boyd (1997, p. 1008) definition of TO as a multifactorial construct, we can affirm that the study of TO has a theoretical basis and can be measured through a reliable instrument, the Zimbardo Time Perspective Inventory (ZTPI) for the English-spoken western cultures (Zimbardo \& Boyd, 1999). However, diverse researchers claim that this instrument deserves further study when implementing its use in other languages (Carrelli, Wilberg \& Wilberg, 2011; Milfont, Andrade, Belo \& Pessoa, 2008 ) in order to provide a high reliability in each of its context of use.

In relation to cognitive and learning aspects, TO is probably the aspect of psychological time that has historically been most related to learning processes and outcomes in formal 
education (Fourez, 2004; Schmidt \& Werner, 2007). Therefore, after analyzing the factor structure of the ZTPI in Spanish and comparing the results with those from the previous study conducted by Díaz-Morales (2006), we will focus on the measurement of TO in relation to students' age among a sample of students on onsite, blended and online HE modalities.

In the ZTPI operationalization, past, present, and future temporal frames are subdivided into five subscales or factors: present hedonism; present fatalism; past positivism; past negativism; and future time perspective. Nevertheless, researchers in the field of TO and HE have specifically focused on two of these factors (Malka \& Covington, 2005; Horstmanshof \& Zimitat, 2007): present hedonism (PH) and future orientation (FO or FTP). PH is defined as seeking immediate pleasure, with little regard to risk or concern for consequences. Present hedonist orientation has been positively related in education, to another temporal variables such procrastination, which is studied in relation to academic outcomes among HE students samples (e.g. Clariana, 2013). Furthermore, future oriented individuals are characterized by delay of gratification, as results of the desire to achieve specific long-term goals. Relation to TO in general and FTP in particular has also revealed a positive correlation between time invested studying and their orientation to future (Peetsma, 2000; Peetsma \& Van der Veen, 2011); results on these studies indicate a significant relation among students' FTP and learning performance; with the mediating effect of time invested in learning; that is, adolescent students with a higher FTP presented spent more time studying at home, and showed a higher learning performance (measured in a final exam) than those who were less future-oriented.

Students' age has changed in onsite universities in the last decades by including not only young but also mature students (Concannon, Flynn \& Campbell, 2005) due to the need for lifelong learning solutions. Age is an important variable in the study of the TO because along the lifecycle, this variable shows different tendencies. In general, young adults show a higher FTP and adults a more present orientation (Díaz-Morales, 2006). The existing studies in onsite HE show a higher future orientation among young adults (from 17 to 24 years old) than for older students (Mello \& Worrell, 2006). This could be due to the fact that older, lifelong learners are more focused on the present applications of what they learn. These profiles do not present a high FTP when compared to younger students, who could need a higher orientation to the future to foresee the further benefits of their actual efforts (Van der Veen \& Peetsma, 2011). Finally, Zabel (1995) used the first version of the ZTPI to study the TO pro- 
file of correspondence university courses, the antecedent modality of online education; a total amount of 101 adult students was studied (M=31.04 years-old). Results indicate that participants in the course had more of an orientation to the future than to either past or present.

Albeit these studies on TO and learning, there is still little research on HE modalities different than onsite HE (Romero \& Usart, 2013). However, researchers could take advantage of online learning contexts: they could help monitoring learning variables such as learning performance or time spent in a task or assignment thanks to the amount of data recorded in these environments. On the other hand, students could need a higher degree of self-regulation in order to succeed in these contexts, as they have less time restrictions and guide during the learning process. In this sense, Peetsma (2000) approach could be useful for the analysis of current educational contexts, according to the fact that students' time devoted to learning in lifelong learning and ICT-based learning such as online courses also deals with leveraging of different life domains (Romero, 2011). Also Bembenutty's (2009) study among $250 \mathrm{HE}$ learners points to the fact that students delay gratification according to their "self-regulated learning strategies and also to the motivation-related judgments of the delay versus non-delay alternatives" (p. 351). This delay could mean that the students don't procrastinate on their work, leading to increased time and effort on task, which is measured as key elements to academic success.

Therefore, there is a need to study learners' TO in the present changing scenario of HE in Europe, where the implementation of ICT in general and Virtual Learning Environments (VLE) in particular; together with the Bologna process (Floud, 2006) is changing both the average age of students and the temporal structure of the HE institutions. These changes are discussed in the next section, in order to analyse HE and students' characteristics in general, before constituting a sample of Spanish university students including three different HE institutions: an onsite university, a blended learning institution combining both onsite and virtual activities, and an online HE institution.

\section{Higher Education in Spain}

In this section we review the changes in HE for the last decades and the specific changes on traditional onsite HE institutions, on those universities having moved to a blended 
learning modality, and the online universities. Higher Education in Europe is adapting to the Bologna process, a series of institutional meetings and agreements among European countries aimed to ensure comparability in the standards and quality of HE qualifications (Floud, 2006). Bologna is designed around a more controlled temporal structure of the course through the ECTS, introducing a higher regulation of the learning times where students have to fit in, demanding students a higher self-regulation of their autonomous learning time, and implementing virtual asynchronous learning activities that completely change the pace of traditional $\mathrm{HE}$ into a more flexible but demanding temporal model (Fillion, Limayem, Laferrière \& Robert, 2007) for onsite, blended and online modalities. Following Floud, up to 10-15\% of the students will fail to succeed their HE degrees, probably due to the lack of students' time for learning (Evans, 2009) and the lack of temporal competences for regulating their learning times in the Bologna model; furthermore, Olani (2009), when studying the factors influencing drop-out among HE students, points to self-efficacy beliefs as persistence and performance predictors. Self-efficacy and academic persistence are positively related to FTP by different authors (Epel, Bandura \& Zimbardo, 1999), thus TO could be also studied as a factor influencing drop-out rates in HE.

Traditional, face-to-face universities are still the predominant HE modality in Spain. Onsite HE institutions base their model on classroom attendance and have less temporal flexibility than the rest of the HE models exposed above. Nevertheless, changes in the student demography such as an increasing number of part time students (school leavers take part-time jobs whilst attending university) who have less time for attending classes and studying, are in demand for a blended learning model, reducing the classroom attendance in favor of virtual activities. A great proportion of mature learners engaging in onsite HE do not fit in its temporal constraints and do not continue in onsite HE after their first year.

On the question of how to merge a more flexible HE model into the structure of onsite institutions, there are institutions that have moved towards a combination of onsite classes, together with virtual activities (Padrós, Romero \& Usart, 2011). Blended HE is specially deployed in part time lifelong learning programs attended by mature adults, combining their HE with their professional activities.

Most of the online learners are mature adults having a professional activity. However, currently in Spain there is a growing number of students and an extension of the present profile of the online learner, that is, adults combining professional activity and learning (ONTSI, 
2011). The online modality is nonetheless not only constituted by lifelong learning adult students, but also by younger students that choose to study online despite their possibility to attend an onsite university. E.g., individuals accessing undergraduate programs and younger than 30 years-old represent more than a third of the students in the Universitat Oberta de Catalunya (UOC), the largest Spanish online university with more than 56000 students.

We now analyse the specific profile of Spanish students in HE, in respect with the general population of Spanish adults of the study of Díaz-Morales (2006). The HE population, when compared to adult profiles, constitutes a group that has decided to pursue their postsecondary education on a voluntary basis. Among the HE population, we will differentiate between the younger adults (less than 24 years) and the mature adults (more than 24 years) when analysing the HE students profile of each HE modality.

The younger adults group is mostly engaged in onsite HE, despite a growing number of enrolments in online education (UOC, 2011). Some studies have shown a high FTP among onsite HE students (Van der Veen \& Peetsma, 2011). Most of the adults engaging HE show a medium or high economic and social status (Rodríguez \& Agulló, 1999) and have a particular set of competences that allow them combine their studies with other life aspects such work. These competences may include, following Fillion, Limayem, Laferrière and Robert (2007), characteristics such high autonomy, low anxiety and higher motivation than the general adult population not engaged in HE. Mature learners tend to show a more present orientation than the younger HE students.

\section{Aims}

In the following sections we present the study of the ZTPI in Spanish focused on the particular population of Spanish HE students that aims to determine if this inventory could be considered as a valid and reliable instrument among HE students. With this purpose, we conducted an exploratory study on the relation between TO and age in the three main modalities of HE in Spain: onsite, blended and online learning. The main aim of this study is therefore to validate the items that compose each temporal factor of the TO and compare it to previous studies' results, both for Spanish and English versions of the instrument. 


\section{Method}

\section{Participants}

The sample is constituted by HE students from three representative institutions of each of the three different modalities of HE in Spain. Firstly, the onsite HE students are sampled from one the major public universities, the Universitat Autonoma de Barcelona (UAB). Secondly, the blended HE students are sampled from ESADE, a business and law school having moved towards a blended learning model. Thirdly, the online HE students are sampled from the major online university in Spain, the UOC. Age ranges from 18 to 57 years old $(\mathrm{M}=31.21$; $\mathrm{SD}=8.79)$; in particular, for $\mathrm{UAB} \mathrm{n}=58$, age range (18-55), ESADE, $\mathrm{n}=89$; age range (21-51), and UOC, n=103; age range (19-57). Students participated in a voluntary basis, and finally, 250 participants filled the ZTPI in its Spanish version, accessing an online questionnaire web page hosted by LimeSurvey.

\section{Measures}

The ZTPI is an instrument with 56 items representing five independent factors described by Zimbardo and Boyd (1999). Each item is rated using a 5-point Likert scale (1 = strongly disagree, and $5=$ totally agree). The Spanish version of the ZTPI has been validated through a psychometric study conducted by Díaz-Morales (2006) among a sample of Spanish adults ( $\mathrm{n}=$ 756), with a factor reliability that ranges from present fatalism $(\alpha=.64)$ to past negative $(\alpha=.80)$. Each factor has been related to different variables. In particular, for HE students, past negative is related to unsatisfactory social relationships, present hedonism to extraversion; future to higher grades, past positivism with high self-esteem, and finally, present fatalism is related to low grades among onsite students.

\section{Procedure}

The ZTPI in the Spanish version by Díaz-Morales (2006) was uploaded in the LimeSurvey web page, together with questions about age and learning context. The URL of the testwas mailed to all the students participating in the three learning modalities; although researchers could have face to face access to the students in the onsite course, we decided to implement the same procedure for the three courses in order to minimize differences among groups and maximize reliability. Participants could access the test during a period of one university term. After the due date, the researchers sent a second mail to remind students that they could still 
fill in the questionnaire during two more weeks. Finally, all the results were downloaded to a spreadsheet file and one participant answer was dismissed because he had not filled in all the 56 items of the inventory.

\section{Statistical Analysis}

After that time, the results were analyzed using IBM SPSS Statistics 20; in particular, a Principal components analysis and a Varimax rotation was conducted, as we expected factors to be ortogonal. Internal reliability of the instrument was studied through Cronbach Alpha coefficient. Confirmatory Factor Analysis (CFA) was also conducted using maximum-likelihood estimation in AMOS software, in order to test the model based on the factor loadings of the exploratory analysis in which items were classified by five latent TP constructs. Finally, the possible correlation between TO and age for the different HE modalities was calculated with an ANOVA.

\section{Results}

Factorial structure of the Spanish version of the ZTPI in Spanish HE students

We first analyze the factorial structure of the Spanish version of the ZTPI, comparing it to Díaz-Morales (2006) and Zimbardo \& Boyd (1999) studies. The same principal component analysis procedure conducted by these authors retrieved in our study (figure 1), as seen from the sedimentation graphic, 5 factors compatible with the ZTPI original structure. 


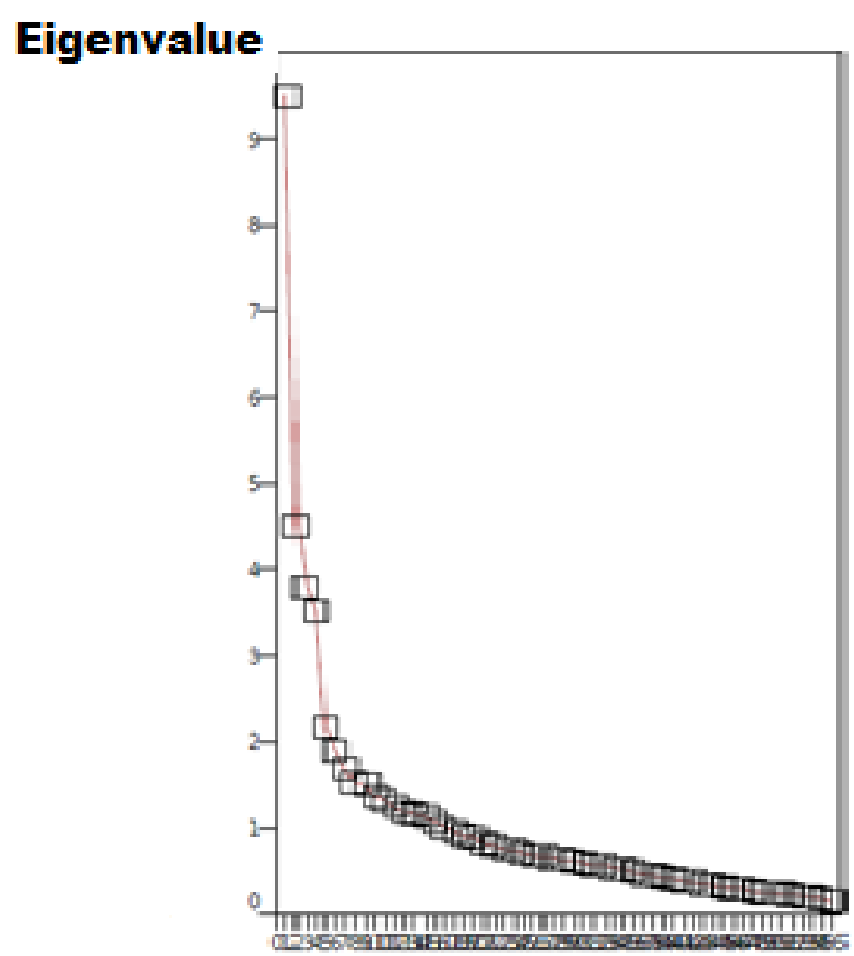

\section{Number of components}

Figure 1 . Sedimentation graphic for the factor analysis of the 56 items

Furthermore, these five factors explain the $38.77 \%$ of the variance, which is higher than the $33.82 \%$ obtained in the Díaz-Morales study, and also higher than the $36 \%$ of the Zimbardo and Boyd (1999) results. Presented in Table 1 the results of the ZTPI structure after the Varimax rotation; differences with the two previous studies are in the two columns on the right.

Past Negative (PN) factor coincides with Díaz-Morales (2006) results besides three items: 29, 47 and 12. Item 29 I get nostalgic about my childhood was measured by Díaz as a Present Positive (PP) sentence, but as PN by our students. Students could be feeling of nostalgia towards' own past can be seen also as negative. Nevertheless, further study is needed to confirm this tendency. The second different item: Life today is too complicated; I would prefer the simpler life of the past, was also measured by Díaz as PP. Nevertheless, our results meet the rating by Zimbardo and Boyd (1999): this item corresponds to a PN sentence. Finally, item 12. When listening to my favorite music, I often lose all track of time was classified as Present Hedonist (PH) in previous studies; although scoring also high in our results for this factor, it was rated as PN in our study. We can discuss that this sentence does not clearly relate to past or present, and that both temporalities adjust to the notion of losing the notion of time, not as future oriented profiles would do. 
Finally, two items coincide with Díaz-Morales (2006) analysis but are different from the original English ZTPI structure. These coincidences in the Spanish version by DíazMorales and our study could be due to cultural peculiarities of the Spanish context compared to the North-American one of the original ZTPI studies. If we take a look at the three statements: 11. On balance, there is much more good to recall than bad in my past; this sentence is rated as negative for the PN factor by Spanish respondents and as positive for PP factor by Americans. There could be an underlying cultural sight of the past as negative in Spain due to the recent civil war, dictatorship and even current crisis. Sentence 51 I keep working at difficult, uninteresting tasks if they will help me get ahead could be related to negative aspects, as stated by Díaz-Morales. Cronbach alpha for this TO factor is $\alpha=.84$ dismissing items 11,12 , 33, 41 and 51; we can therefore assume a high reliability of the PN factor composed of the remaining 11 items in our sample.

Table 1. Factorial structure of ZTPI. Principal components analysis (Varimax rotation)

\begin{tabular}{|c|c|c|c|c|c|c|c|}
\hline & $\mathrm{PN}$ & $\mathrm{PH}$ & FTP & PP & $\mathrm{PF}$ & Díaz & $\mathrm{Z} \& \mathrm{~B}$ \\
\hline $\begin{array}{l}\text { 50. I think about the bad things that have happened to } \\
\text { me in the past. }\end{array}$ & .88 & & & & & & \\
\hline $\begin{array}{l}\text { 22. I've taken my share of abuse and rejection in the } \\
\text { past. }\end{array}$ & .82 & & & & & & \\
\hline $\begin{array}{l}\text { 27. I've made mistakes in the past that I wish I could } \\
\text { undo. }\end{array}$ & .75 & & & & & & \\
\hline $\begin{array}{l}\text { 34. It 's hard for me to forget unpleasant images of my } \\
\text { youth. }\end{array}$ & .73 & & & & & & \\
\hline $\begin{array}{l}\text { 54. I think about the good things that I have missed } \\
\text { out on in my life. }\end{array}$ & .72 & & .32 & & & & \\
\hline $\begin{array}{l}\text { 16. Painful past experiences keep being replayed in my } \\
\text { mind. }\end{array}$ & .70 & & & & & & \\
\hline $\begin{array}{l}\text { 36. Even when I am enjoying the present, I am drawn } \\
\text { back to comparisons with similar past experiences. }\end{array}$ & .58 & & & & & & \\
\hline $\begin{array}{l}\text { 04. I often think of what I should have done differently } \\
\text { in my life. }\end{array}$ & .57 & & & .20 & & & \\
\hline $\begin{array}{l}25 \text {. The past has too many unpleasant memories that I } \\
\text { prefer not to think about }\end{array}$ & .57 & & & & & & \\
\hline 29. I get nostalgic about my childhood. & .50 & .29 & & & .22 & PP & PP \\
\hline $\begin{array}{l}\text { 47. Life today is too complicated; I would prefer the } \\
\text { simpler life of the past. }\end{array}$ & .44 & & & & .31 & PP & \\
\hline $\begin{array}{l}\text { 11. On balance, there is much more good to recall than } \\
\text { bad in my past. }\end{array}$ & .35 & & & & & & PP \\
\hline $\begin{array}{l}\text { 51. I keep working at difficult, uninteresting tasks If } \\
\text { they will help me get ahead. }\end{array}$ & .24 & & & & & & FTP \\
\hline 33. Things rarely work out as I expected. & .30 & & & & .33 & & \\
\hline $\begin{array}{l}\text { 12. When listening to my favorite music., I often lose all } \\
\text { track of time. }\end{array}$ & .22 & & & .20 & & $\mathrm{PH}$ & $\mathrm{PH}$ \\
\hline $\begin{array}{l}\text { 41. I find myself tuning out when family members talk } \\
\text { about the way things used to be. }\end{array}$ & .17 & & & & & & \\
\hline
\end{tabular}




\begin{tabular}{|c|c|c|c|c|c|c|c|}
\hline 42. I take risks to put excitement in my life & & .90 & & & & & \\
\hline 31. Taking risks keeps my life from becoming boring. & & .80 & & & & & \\
\hline $\begin{array}{l}\text { 48. I prefer friends who are spontaneous rather than } \\
\text { predictable. }\end{array}$ & & .56 & & & & & \\
\hline 26. It is important to put excitement in my life. & & .50 & & & & & \\
\hline $\begin{array}{l}\text { 46. I find myself getting temptations when I know that } \\
\text { there is work to be done. }\end{array}$ & & .41 & -.23 & & & & \\
\hline $\begin{array}{l}\text { 32. It is more important for me to enjoy life's journey } \\
\text { than focus only on the destination. }\end{array}$ & & .41 & -.23 & .40 & 21 & & \\
\hline $\begin{array}{l}\text { 19. Ideally, I would live each day as fully as possible, } \\
\text { one day at a time. }\end{array}$ & & .39 & & & & & \\
\hline 08. I do things impulsively. & & .26 & & & & & \\
\hline 44. I often follow my heart more than my head. & & 18 & & & & & \\
\hline 55. I like my close relationships to be passionate. & & 15 & & & & & \\
\hline 17. I try to live my life each day as if it were my last. & & .13 & & & & & \\
\hline $\begin{array}{l}\text { 45. I am able to resist temptations when I know there is } \\
\text { work to be done. }\end{array}$ & & & .71 & .25 & & & \\
\hline $\begin{array}{l}\text { 13. Meeting tomorrow's deadlines and doing other nec- } \\
\text { essary work comes before tonight's play }\end{array}$ & & & .65 & & & & \\
\hline $\begin{array}{l}\text { 40. I complete projects on time by making steady pro- } \\
\text { gress. }\end{array}$ & & & .47 & & & & \\
\hline $\begin{array}{l}\text { 52. Spending what I earn on pleasures today is better } \\
\text { than saving for tomorrow's security. }\end{array}$ & & .26 & -.45 & & & $\mathrm{PH}$ & $\mathrm{PH}$ \\
\hline 56. There will always be time to catch up on my work. & & & -.45 & & & & \\
\hline $\begin{array}{l}\text { 28. I feel that it's more important to enjoy what you're } \\
\text { doing than to get work done on time. }\end{array}$ & & & -.39 & & & $\mathrm{PH}$ & $\mathrm{PH}$ \\
\hline $\begin{array}{l}\text { 10. When I want to achieve something, I set goals and } \\
\text { consider specific means for reaching those goals. }\end{array}$ & & & .35 & & & & \\
\hline 18. It upsets me to be late for appointments. & & & .35 & & & & \\
\hline $\begin{array}{l}\text { 21. I meet my obligations to friends and authorities on } \\
\text { time. }\end{array}$ & & & .30 & & & & \\
\hline $\begin{array}{l}\text { 35. It takes joy out of the process and flow of my activi- } \\
\text { ties, if I have to think about goals, outcomes, and prod- } \\
\text { ucts. }\end{array}$ & & & 27 & & & & \\
\hline $\begin{array}{l}\text { 30. Before making a decision, I weigh the costs against } \\
\text { the benefits . }\end{array}$ & & & .24 & & -.23 & & \\
\hline $\begin{array}{l}\text { 20. Happy memories of good times spring readily to } \\
\text { mind. }\end{array}$ & & & .13 & & & PP & PP \\
\hline $\begin{array}{l}\text { 49. I like family rituals and traditions that are regularly } \\
\text { repeated }\end{array}$ & & & .31 & .61 & & & \\
\hline $\begin{array}{l}\text { 05. My decisions are mostly influenced by people and } \\
\text { things around me. }\end{array}$ & & & & .54 & & & $\mathrm{PN}$ \\
\hline 07. It gives me pleasure to think about my past. & .26 & & & .32 & & & \\
\hline $\begin{array}{l}\text { 01. I believe that getting together with one's friends to } \\
\text { party is one of life's important pleasures. }\end{array}$ & & & & .50 & & $\mathrm{PH}$ & PH \\
\hline $\begin{array}{l}\text { 02. Familiar childhood sights, sounds, smells often } \\
\text { bring back a flood of wonderful memories,. }\end{array}$ & & & & .23 & & & \\
\hline $\begin{array}{l}\text { 14. Since whatever will be will be, it doesn't really mat- } \\
\text { ter what I do. }\end{array}$ & .33 & & .51 & -.32 & .91 & & \\
\hline $\begin{array}{l}\text { 37. You can't really plan for the future because things } \\
\text { change so much. }\end{array}$ & & & & & .77 & & \\
\hline $\begin{array}{l}\text { 39. It doesn't make sense to worry about the future, } \\
\text { since there is nothing that I can do about it anyway. }\end{array}$ & & & & & .56 & & \\
\hline $\begin{array}{l}\text { 38. My life path is controlled by forces I cannot influ- } \\
\text { ence. }\end{array}$ & .25 & & & & .52 & & \\
\hline
\end{tabular}




\begin{tabular}{|c|c|c|c|c|c|c|}
\hline 24. I take each day as it is rather than try to plan it out. & & -.23 & & .47 & & \\
\hline 53. Often luck pays off better than hard work. & & -.42 & & 34 & & \\
\hline $\begin{array}{l}\text { 09. If things don't get done on time, I don't worry about } \\
\text { it. }\end{array}$ & & -.24 & .21 & .28 & FTP & FTP \\
\hline 03. Fate determines much in my life. & .27 & & & 28 & & \\
\hline $\begin{array}{l}\text { 15. I enjoy stories about how things used to be in the } \\
\text { «good old times». }\end{array}$ & & & & 27 & PP & PP \\
\hline $\begin{array}{l}\text { 06. I believe that a person's day should be planned } \\
\text { ahead each morning. }\end{array}$ & & & .25 & -.37 & FTP & FTP \\
\hline 23. I make decisions on the spur of the moment. & & -.20 & & 26 & & PH \\
\hline 43. I make lists of things to do. & & & & -.20 & FTP & FTP \\
\hline
\end{tabular}

Note. Factor loadings <.2 are suppressed. PN: Past Negative; PH: Present Hedonist; FTP: Future Time Perspective; PP: Past Positive; PF: Present Fatalist

Present Hedonism (PH) factor results totally coincide with the two previous studies (Díaz-Morales, 2006; Zimbardo \& Boyd, 1999). Dismissing items 55 and 17 because its low loading (<.32), Cronbach alpha for this TO factor $(\alpha=.77)$ indicates an acceptable reliability of the PH scale. We could interpret the coincidence in the PH in all the contexts because the present orientation is less influenced by the specific cultural aspects that affects mainly the past, and in a lesser degree, it is also related to changes in future perception.

For Future Time Perspective (FTP) factor, there are some important differences in three items (20, 28 and 52) when compared to the previous studies. Item 20 is removed because of its low scoring in the factor $(<0.30)$; difference in this item Happy memories of good times spring readily to mind, (PP item in previous studies), could be based on the fact that it is a positive sentence for students, and they somehow relate it to a positive future. Items 28 and 52 are also removed after the study of Cronbach alpha, that rises from $\alpha=.50$ to $\alpha=.63$ after removing these sentences. For item 52 Spending what I earn on pleasures today is better than saving for tomorrow's security, differences could be explained by the valence of the factor, as it is rated negatively to FTP in our study, and rated as a positive PH item factor in the other studies. The valence of the items could be affected by the cultural differences of each context. For this reason, we believe the results should be further studied, due to the low internal reliability factor of this particular subscale. However, Cronbach alpha coefficients higher than .60 have been argued as acceptable for research purposes (Clark \& Watson, 1995), especially for broad constructs, such as the ZTPI. Thus, following these recommendations, the scale has acceptable reliability.

Past Positivism (PP) items do not totally coincide with previous studies; there are two sentences that do not coincide with Zimbardo \& Boyd (1999) and one difference with Díaz- 
Morales (2006). We can analyze these two items in order to understand these results: in item 5: My decisions are mostly influenced by people and things around me, we meet DíazMorales results; this could be due to cultural differences (Jones \& Brown, 2005; Shirai, 1994), as social relations in Spain are perceived as positive, while in the US, it is seen as a past negative sentence. Finally, item 1 I believe that getting together with one's friends to party is one of life's important pleasures was previously rated as a $\mathrm{PH}$ item, while, in our sample, it is related to positive thoughts of the past. This could be explained reading the sentence as related to the preference for social relations of PP profiles. The higher measured Cronbach alpha for the PP factor is $\alpha=.47$, and is found when the 5 items of this factor are maintained. This result deserves further study in other samples, and it meets the Milfont, Andrade, Belo and Pessoa (2008) measure among a Brazilian sample, where PP factor has only 6 items and the Cronbach alpha is similar (.46)

Finally, there are 4 different items in the Present Fatalist (PF) factor, compared to the previous Spanish ZTPI study. Item 9 If things don't get done on time, I don't worry about it scored high and negative in FTP, as in the two previous studies, but higher for positive PF; items 6: I believe that a person's day should be planned ahead each morning, which were previously assigned to positive FTP sentences, but in our study are negative PF sentences. We therefore meet the Zimbardo \& Boyd's (1999) conclusions, from these 3 sentences, that there is a negative correlation between a high orientation to future and a fatalist, fate-based sight of life. Finally, item 15 I enjoy stories about how things used to be in the good old times, was previously defined as a PP sentence, while our results relate it to PF; we could think that students with high PF, as not motivated with present or future, prefer to remember past events. Cronbach alpha for this last TO factor is $\alpha=.66$, that rises to .71 if we dismiss item 6 .

Confirmatory factor analysis was performed (via maximum likelihood estimation) on the data from a new sample of students in the UOC $(\mathrm{N}=316)$ in order to avoid sample bias following Howell (2006). All of the 45 EFA resulting items present a significant relationship with the latent factor on which they were expected to load according to the EFA, that is, all items show a standardized scoring above .35 except items 1 (.241), 9(.284) and 43 (-.155). All of these sentences were found to be in different factors compared to previous studies, that is why the authors conducted another CFA moving these items to the theoretical (Zimbardo \& Boyd, 1999) structure. However, results were similar and neither significant scorings nor $\mathrm{R}^{2}$ for these particular items were found. We decided to retain the items, according to Zimbardo 
\& Boyd, due to the theoretical importance of these sentences, and also based on our model presents an acceptable goodness of fit according to the $X^{2} / d f$ ratio (Carmines \& McIver, 1981), which applies when the number of degrees of freedom is high (in our model, $d f=1034$ ). In particular, our ratio is 2.11 , which in fact is very similar to the Zimbardo \& Boyd value (2.30), also a RMSEA of .059 (<.060) allow us to accept the 5 factor model of the Spanish ZTPI, with a 45 items structure.

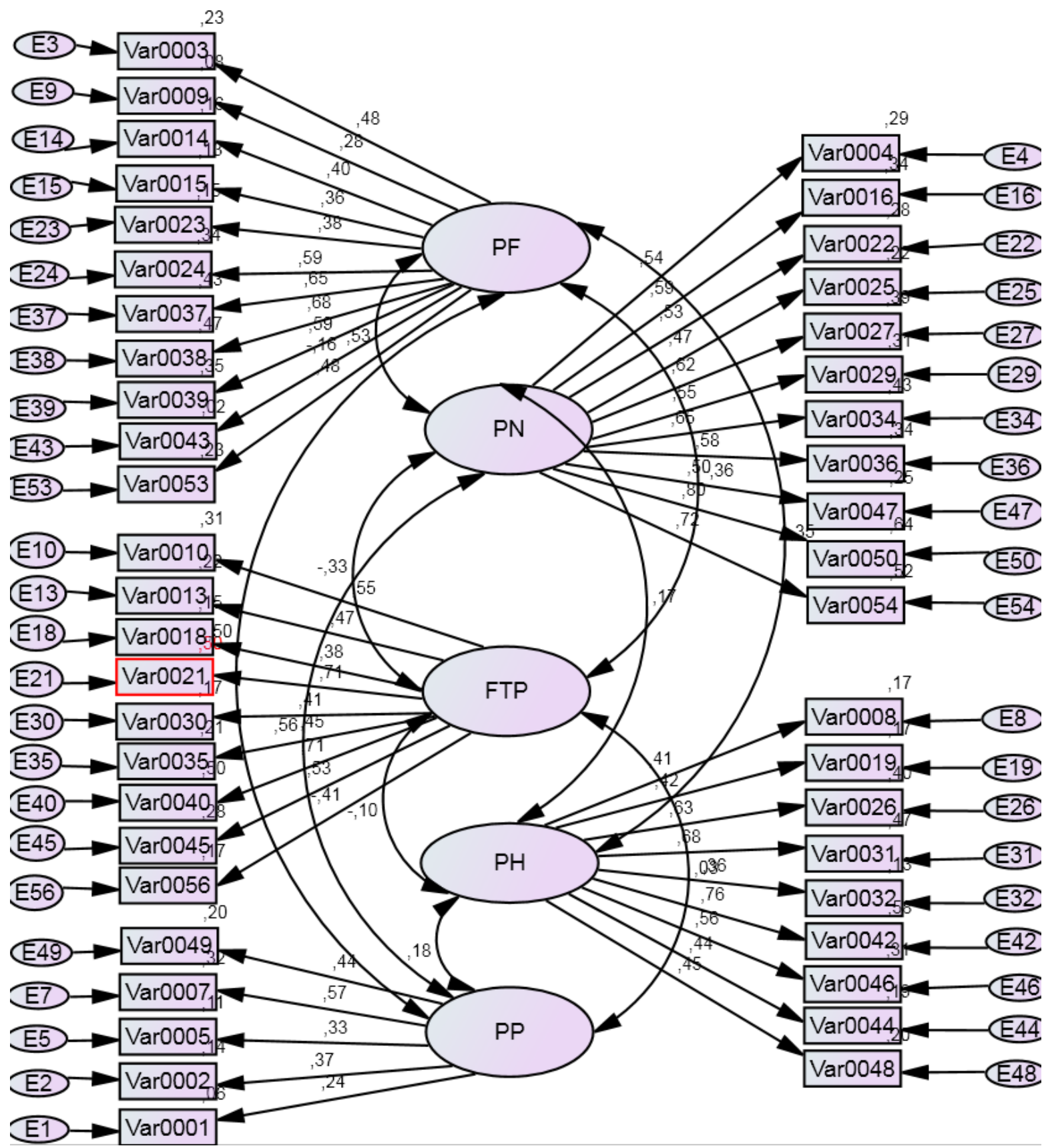

Figure 2. Confirmatory model with standardized regression weights and squared correlations. 
Relation of the TO and age for the onsite, blended and online HE

After the factor analysis and internal reliability study of the ZTPI in Spanish, we focus on the validity of the instrument by measuring the relation between TO and age for the three different learning modalities. We analyze the different factors of TO in relation to age and university model. Age ranges are explicitated for 18 to 57 years old; nevertheless, due to the limited number of older students and the focus of our study, we do not discuss the results for this latter group. In order to conduct the correlation analysis, we measured the scorings for each factor after rejecting item 28. Results for age and HE modality related to students' TO are in Table 2.

Table 2. Average results for the different TO factors, age range and HE modality

\begin{tabular}{|c|c|c|c|c|c|c|c|c|c|}
\hline \multirow{3}{*}{$\begin{array}{c}\begin{array}{c}\text { ZTPI Fac- } \\
\text { tor }\end{array} \\
\text { PN }\end{array}$} & \multirow{3}{*}{$\begin{array}{c}\text { Age range } \\
18-27(\mathrm{~N}=77)\end{array}$} & \multicolumn{6}{|c|}{ Higher Education Modality } & \multirow{2}{*}{\multicolumn{2}{|c|}{ Total }} \\
\hline & & \multicolumn{2}{|c|}{ Onsite } & \multicolumn{2}{|c|}{ Blended } & \multicolumn{2}{|c|}{ Online } & & \\
\hline & & $\begin{array}{c}M \\
3.02\end{array}$ & $\begin{array}{c}S D \\
(0.79)\end{array}$ & $\begin{array}{c}M \\
2.30\end{array}$ & $\begin{array}{c}S D \\
(0.28)\end{array}$ & $\begin{array}{c}M \\
2.89\end{array}$ & $\begin{array}{c}S D \\
(0.69)\end{array}$ & $\begin{array}{c}M \\
2.90\end{array}$ & $\begin{array}{c}S D \\
(0.64)\end{array}$ \\
\hline & $28-37(\mathrm{~N}=110)$ & 2.72 & $(0.62)$ & 2.32 & $(0.51)$ & 2.48 & $(0.51)$ & 2.38 & $(0.57)$ \\
\hline & $38-47(\mathrm{~N}=53)$ & 2.84 & $(0.52)$ & 2.00 & $(0.28)$ & 2.65 & $(0.67)$ & 2.34 & $(0.52)$ \\
\hline & $48-57$ & 2.97 & $(0.60)$ & 2.28 & $(0.47)$ & 2.48 & $(0.33)$ & 2.54 & $(0.29)$ \\
\hline & Total & 2.85 & $(0.65)$ & 2.24 & $(0.47)$ & 2.62 & $(0.60)$ & 2.54 & $(0.62)$ \\
\hline $\mathrm{PH}$ & $18-27$ & 3.45 & $(0.63)$ & 3.18 & $(0.49)$ & 3.31 & $(0.49)$ & 3.41 & $(0.55)$ \\
\hline & $28-37$ & 3.42 & $(0.72)$ & 3.25 & $(0.45)$ & 3.12 & $(0.48)$ & 3.2 & $(0.51)$ \\
\hline & $38-47$ & 3.42 & $(0.35)$ & 3.16 & $(0.65)$ & 3.14 & $(0.50)$ & 3.14 & $(0.49)$ \\
\hline & $48-57$ & 3.22 & $(0.38)$ & 3.41 & $(0.39)$ & 3.21 & $(0.50)$ & 3.19 & $(0.41)$ \\
\hline & Total & 3.41 & $(0.60)$ & 3.22 & $(0.50)$ & 3.18 & $(0.49)$ & 3.25 & $(0.53)$ \\
\hline FTP & $18-27$ & 4.01 & $(0.41)$ & 4.17 & $(0.36)$ & 3.91 & $(0.45)$ & 3.87 & $(0.45)$ \\
\hline & $28-37$ & 4.01 & $(0.41)$ & 3.83 & $(0.49)$ & 4.01 & $(0.36)$ & 4.03 & $(0.45)$ \\
\hline & $38-47$ & 3.81 & $(0.52)$ & 4.05 & $(0.48)$ & 4.06 & $(0.41)$ & 4.02 & $(0.41)$ \\
\hline & $48-57$ & 3.88 & $(0.71)$ & 3.88 & $(0.71)$ & 3.68 & $(0.34)$ & 3.75 & (0.38) \\
\hline & Total & 3.96 & $(0.46)$ & 3.98 & $(0.49)$ & 3.97 & $(0.40)$ & 3.97 & $(0.44)$ \\
\hline PP & $18-27$ & 3.29 & $(0.33)$ & 3.01 & $(0.41)$ & 3.29 & $(0.37)$ & 3.28 & $(0.43)$ \\
\hline & $28-37$ & 3.18 & $(0.53)$ & 2.99 & $(0.40)$ & 3.23 & $(0.45)$ & 3.12 & $(0.42)$ \\
\hline & $38-47$ & 3.40 & $(0.34)$ & 2.98 & $(0.40)$ & 3 & $(0.40)$ & 2.95 & $(0.44)$ \\
\hline & $48-57$ & 3.36 & $(0.62)$ & 2.8 & $(0.38)$ & 2.66 & $(0.15)$ & 2.82 & (0.30) \\
\hline & Total & 3.28 & $(0.45)$ & 2.97 & $(0.40)$ & 3.16 & $(0.44)$ & 3.12 & $(0.44)$ \\
\hline PF & $18-27$ & 2.95 & $(0.45)$ & 1.96 & $(0.46)$ & 2.69 & $(0.42)$ & 2.77 & $(0.49)$ \\
\hline & $28-37$ & 2.82 & $(0.51)$ & 2.21 & $(0.54)$ & 2.52 & $(0.42)$ & 2.34 & $(0.53)$ \\
\hline & $38-47$ & 2.87 & $(0.35)$ & 1.99 & $(0.37)$ & 2.49 & $(0.52)$ & 2.27 & $(0.51)$ \\
\hline & $48-57$ & 2.85 & $(0.22)$ & 2.18 & $(0.33)$ & 2.55 & $(0.37)$ & 2.48 & $(0.38)$ \\
\hline & Total & 2.87 & $(0.44)$ & 2.09 & $(0.48)$ & 2.56 & $(0.44)$ & 2.46 & $(0.55)$ \\
\hline
\end{tabular}

PN: Past Negative; PH: Present Hedonist; FTP: Future Time Perspective; PP: Past Positive; PF: Present Fatalist 
Past Negativism significantly decreases with age; youngsters have a higher PN than older students $F(3,249)=5.63 ; p<0.001$. Díaz-Morales (2006) analysis failed to find a significant decrease of PN with age; this difference could be because young adults in the present sample have a higher PN due to the economic and social situation in Spain when compared to 2006 youngsters. Furthermore, comparing HE models, significant differences show among the 3 modalities $F(2,249)=7.08 ; p<0.001$; in particular, onsite students have a significantly higher PN than online students, and the latter have also higher PN than the blended-learning students in our study (Tukey test, $\mathrm{p}<0.05$ ). These differences could be related to the generally higher economic status of ESADE students when compared to public universities students (Rodríguez \& Agulló, 1999).

Present Hedonism decreases with age, as in Díaz-Morales (2006) study, but not significantly. Nevertheless, there are significant differences among universities, in particular, online and blended-learning students rate significantly lower in PH than onsite and (Tukey test, $p<0.05$ ). This results could be showing a preference of $\mathrm{PH}$ for onsite learning, although the limited number of studies in this field, some authors such Zabel (2004) show a low number of PH profiles in distant education HE students and in b-learning profiles (Usart \& Romero, 2012) when compared to FTP students.

No significant differences for the Future factor with age range were retrieved $F(2,249)=1.01 ; p=0.36$. Results are therefore different than for the Díaz (2006) sample, these differences could be due to the fact that HE students have, in average, a high future orientation than population in general (Van der Veen \& Peetsma, 2011).

Past Positive presents a decrease with age in general $F(2,249)=4.74 ; p<0.001$; nevertheless, if we take a look to the different HE modalities $F(3,102)=5.95 ; p<0.001$, only for online students this decrement is significant (Tukey test, $p<0.05$ ), in line with the previous studies on students' TO, PP profiles are keen for social relations; these interactions are easier to find in face to face modalities rather than in online HE. Younger students could access the online university at a similar rate that they access onsite or blended options, but be gradually leaving these studies in regards of a more social model.

Finally, Present Fatalism (PF) shows no significant differences with age in general, nevertheless, onsite students present a significantly higher PF factor than for online and 
blended learning students $F(3,102)=32.06 ; p<0.001$; we could suppose that students in our blended learning modality have a lower PF factor because of the particular profile of blendedlearning HE students, who are less likely to be first-year students and may seek some degree of flexibility or independence according to the study of Hagel and Shaw (2007, p. 376), which could explain a higher confidence and lower PF.

\section{Discussion}

We have studied the factor structure and internal reliability of ZTPI in its Spanish version; in particular, we have compared it with the previous Díaz-Moreno (2006) results, and confirmed the reliability and external validity of the instrument among two different samples of Spanish adult students. Although results for internal reliability and validity are acceptable and similar to the previous studies, we consider further research with greater samples of participants and interviews or focus groups with participants could help increasing internal reliability for the FTP factor and understanding low scorings in CFA for four of the items. Furthermore, same results have been met for five items when compared to Díaz-Morales study; this could be explained as an experimental support of the TO theory on the socio-cultural and linguistic aspect of this construct discussed by Zimbardo and Boyd (1999) and D'Alessio, Guarino, De Pascalis and Zimbardo (2003).

Secondly, the validity of the instrument has been tested in a sample of HE students in Spain. The differences shown, in particular for the FTP factor, have been compared to a general adult population sample (Díaz-Moreno, 2006), and could be due to the particular profile of HE students; adult learners are expected to present a higher FTP than other population due to their delay of gratification and future goals (Van der Veen \& Peetsma, 2011). Concerning the relation of students' age and TO, our results could give a first, indicative direction for helping institutions adapting their offer of online, onsite and blended courses to the different students' profiles, based on their TO. In all the contexts, HE institutions could proceed to a TO diagnosis of their students and personalise the level of feedback need for more present oriented students and the level of future implications of the learning objectives to be addressed to the more FTP ones. Social relations developed informally in onsite, but also through the teamwork in blended and online learning activities could help the past oriented students to have a more balanced TO. HE should definitively take into consideration the TO 
of their students in order to reduce the level of current failure and increase the students engagement and performance.

\section{Conclusions}

Concerning the relation of students' age and TO, the significant general decrease of past oriented students with age shown in our study deserves further research, in particular, focusing on online HE students. Nevertheless, our results could give a first, indicative direction for helping institutions adapting their offer of online, onsite and blended courses to the different students' profiles, based on their TO. Moreover, the results in this study could help prospective HE students to choose their HE modality according to their TO. Although future oriented students would perform equally in the different modalities, students showing a different PO should consider to choose their HE modality according to their TO. Youngest students with a high PP could be recommended to choose a blended model that reinforced their social aspects and help continue their studies. PH students could better succeed in onsite HE, where the temporal structure forces them to regulate part of their learning times, and overcome the temptations of hedonism that could be more difficult to avoid in flexible environments such blended and online HE. In all the contexts, HE institutions could proceed to a TO diagnosis of their students and personalise the level of feedback need for more present oriented students and the level of future implications of the learning objectives to be addressed to the more FO ones. Social relations developed informally in onsite, but also through the teamwork in blended and online learning activities could help the past oriented students to have a more balanced TO. HE should definitively take into consideration the TO of their students in order to reduce the level of current failure and increase the students engagement and performance. 


\section{References}

Bembenutty, H. (2009). Academic delay of gratification, self-regulation of learning, gender differences, and expectancy-value. Personality and Individual Differences, 46, 347-352. doi: 10.1016/j.paid.2008.10.028

Block, R.A. (1974). Memory and the experience of duration in retrospect. Memory and Cognition 2, 153-160. doi: 10.3758/bf03197508

Carelli, M. G., Wiberg, B., \& Wiberg, M. (2011). Development and Construct Validation of the Swedish Zimbardo Time Perspective Inventory, European Journal of Psychological Assessment, 27 (4), 220-227. doi: 10.1027/1015-5759/a000076

Carmines, E.G., \& McIver, J.D. (1981). Analyzing models with unobserved variables: Analyss of covariance structures. In G.W. Bohinstedt \& E.F: Borgatta (Eds.) Social measurement: current issues (pp. 65-115). Beverly Hills, CA: Sage.

Clariana, M. (2013). Personality, procrastination and cheating in students from different university degree programs. Electronic Journal of Research in Educational Psychology, 11(2), 451-472. doi: 10.14204/ejrep.30.13030

Concannon, F., Flynn, A., \& Campbell, M.(2005). What campus-based students think about the quality and benefits of e-learning. British Journal of Educational Technology, 36 (3), 501-512. doi: 10.1111/j.1467-8535.2005.00482.x

D'Alessio, M., Guarino, A., De Pascalis, V., \& Zimbardo, P. G. (2003). Testing Zimbardo's Stanford Time Perspective Inventory (STPI)-Short Form An Italian Study. Time \& Society, 12(2-3), 333-347. doi: 10.1177/0961463x030122010

Díaz-Morales, J. F. (2006). Estructura factorial y fiabilidad del Inventario de Perspectiva Temporal de Zimbardo. Psicothema 18(3), 565-71.

Evans, T. N. (2009). An investigative study of factors that influence the retention rates in online programs at selected state, state-affiliated, and private universities. Robert Morris University, 2009. 3388741.

Epel, E. S., Bandura, A., \& Zimbardo, P. G. (1999). Escaping homelessness: The influences of self-efficacy and time perspective on coping with homelessness. Journal of Applied Social Psychology, 29, 575-596. doi: 10.1111/j.1559-1816.1999.tb01402.x

Fillion, G., Limayem, M., Laferrière, T., \& Robert, M. (2007). Integrating ict into higher education: a study of onsite vs online students'. Academy of Educational Leadership Journal, 11 (2), ProQuest Central, 45. doi: 10.4018/jwltt.2008040104 
Floud, R. (2006). The bologna process. Change, 38(4), 8-15. doi: 10.3200/CHNG.38.4.815Fourez, M (2009). Impoverished students' perspectives of time. ProQuest Dissertations and Theses

Gjesme, T. (1983). On the concept of future time orientation: consideration of some functions' and measurements' implications. International journal of psychology, 18, 443-461. doi: $10.1080 / 00207598308247493$

Hagel, P., \& Shaw, R. (2007). Choosing ICT? A segmentation analysis of students' preferences for hybrid study mode. In ICT: Providing choices for learners and learning. Proceedings ascilite Singapore.

Horstmanshof, L., \& Zimitat, C. (2007). Future time orientation predicts academic engagement among first year university students. British Journal of Educational Psychology, 77(3), 703-718. doi: 10.1348/000709906x160778

Howell, D.C. (2006). Statistical methods for Psychology. Boston: Wadsworth Publishing

Jones, J., \& Brown, W. T. (2005). Any time is Trinidad time! Cultural Variations in the Value and Function of time. In Strathman, A., \& Joireman, J. (Eds.). Understanding behavior in the context of time: Theory, research, and applications (pp._306-326). Mahwah, N.J: Lawrence Erlbaum Associates, Publishers.

Lewin, K. (1942). Time perspective and morale. In G.Watson (Ed.), Civilian morale (pp. 4870). New York: Houghton Mifflin.

Malka, A., \& Covington, M. V. (2005). Perceiving school performance as instrumental to future attainment: effects on graded performance. Contemporary Educational Psychology, 30 (1), 60-80. doi: 10.1016/j.cedpsych.2004.04.001

Mello, Z. R., \& Worrell, F. C. (2006). The Relationship of Time Perspective to Age, Gender, and Academic Achievement among Academically Talented Adolescents. Journal for the Education of the Gifted, 29(3), 271-289. doi: 10.1177/0016986206296655

Milfont, T. L., Andrade, P. R., Belo, R. P., \& Pessoa, V. S. (2008). Testing Zimbardo Time Perspective Inventory in a Brazilian sample. Interamerican Journal of Psychology, 42, 4958.

New Media Corsortium and EDUCAUSE (2012) The horizon repor. The New Media Corsortium, Austin, Texas. 
Nurmi, J. (1991). How do adolescents see their future? A review of the development of future orientation and planning. Developmental Review, 11(1), 1-59. doi: 10.1016/0273$\underline{2297(91) 90002-6}$

Nuttin, J. R. (1964). The future time perspective in human motivation and learning. Acta Psychologica, 23, 60-82. doi: 10.1016/0001-6918(64)90075-7

Olani, A. (2009). Predicting first year university students' academic success. Electronic Journal of Reseach in Educational Psychology, 7(3), 1053-1072. ISSN: 1696-2095

Observatorio Nacional de las Telecomunicaciones y de la Sociedad de la Información. (2011). Indicadores de Seguimiento de la Sociedad de la Información por Comunidades Autonomas, retrieved [16/01/2013] from: http://www.red.es/media/registrados/201103/1299075753424.pdf?aceptacion=99abe2c79cdcaf1fec27cc2244c4e64c

Padrós, A. Romero, M., \& Usart, M. (2011). Developing serious Games: Form Face to face to a Computer-based Modality. E-learning papers, 25, 1-12

Peetsma, T. (2000). Future time perspective as a predictor of school investment. Scandinavian Journal of Educational Research, 44(2), 177-192. doi: 10.1080/713696667

Peetsma, T., \& Van der Veen, I. (2011). Relations between the development of future time perspective in three life domains, investment in learning, and academic achievement. Learning and Instruction, 21(3), 481-494. doi: 10.1016/j.learninstruc.2010.08.001

Rodríguez, J., \& Agulló, E. (1999). Estilos de vida, cultura, ocio y tiempo libre de los estudiantes universitarios, Psicothema, 11(2), 247-259

Romero, M., \& Usart, M. (2013). Time Factor in the Curriculum Integration of Game-Based Learning. In S. de Freitas, M. Ott, M. Popescu \& I. Stanescu (Eds.), New Pedagogical Approaches in Game Enhanced Learning: Curriculum Integration (pp. 248-266 ) IGI Global. doi: $\underline{10.4018 / 978-1-4666-3950-8 . \operatorname{ch} 013}$

Shirai, T. (1994). A study on the construction of Experiential Time Perspective Scale. Shinrigaku kenkyu. The Japanese Journal of Psychology, 65(1), 54-60. doi: 10.4992/jjpsy.65.54

Schmidt J. T., \& Werner C. H. (2007). Designing Online Instruction for Success: Future Oriented Motivation and Self-Regulation. The Electronic Journal of e-learning, 5(1), 69 -78

Van der Veen, I., \& Peetsma, T. (2011). Motivated for leisure in the future: A person-centred longitudinal study in the lowest level of secondary education. Learning and Individual Differences, 21(2), 233-238. doi: 10.1016/j.lindif.2010.12.004 
Zabel, E. (1995). Correspondence course completion rates. PhD dissertation. Retrieved from http://etd.lib.ttu.edu/theses/available/etd-0107200931295009342592/unrestricted/31295009342592.pdf [10/01/2013]

Zakay, D. (1989). Subjective time and attentional resource allocation: an integrated model of time estimation. In I. Levin \& D. Zakay (Eds.), Time and human cognition: a life-span perspective (pp. 365-397). Amsterdam: North-Holland.

Zimbardo, P. G., \& Boyd, J. N. (1999). Putting Time in Perspective: A Valid, Reliable Individual-difference Metric. Journal of Personality and Social Psychology, 77, 1271-1288. doi: $\underline{10.1037 / / 0022-3514.77 .6 .1271}$ 
Usart, M. \& Romero, M.

[This page intentionally left blank] 